\title{
Learning to Know And Learning to do In Science Againts Critical Thinking Ability
}

\author{
${ }^{1}$ Eka Trisnawati, ${ }^{2}$ Rizki Noor Prasetyono \\ 1eka.psnbio@gmail.com, ${ }^{2}$ rizkiprasetyono@gmail.com \\ ${ }^{1}$ Pharmacy Peradaban University Brebes, Indonesia, ${ }^{2}$ Electrical Engineering Peradaban University \\ Brebes, Indonesia
}

\begin{abstract}
This study aims to determine the effect of learning to know and learning to do with critical thinking skills. It is experimental research using the One-Shot Case Study Design. Bumiayi 1 Junior High School is the place where the writer conducted this research in AprilMay 2018. The sample consisted of 32 students, using Simple Random Sampling. Data collection techniques are observation and tests. Simple linear regression and multiple regression tests are used to analyze the data. The results showed that there is a correlation value of 0,848 (very strong), $\mathrm{R}$ square of 0,719 ; and $\mathrm{F}$ counts at 0.00 . Therefore, it can be concluded that learning to know and learning to do influence critical thinking skills.
\end{abstract}

Keywords: learning to know, learning to do, science, critical thinking

\section{Introduction}

\subsection{Background}

The 21st century shows the era of knowledge and technology in the world of education. Various skills are needed, one of which is critical thinking skills.. They are the skills to use multiple organized strategies to solve a problem by considering specific points of view and evaluating personal opinions and others systematically [1].

Critical thinking is critical to be mastered by students. However, only about $20 \%$ of students who have critical thinking skills in science subjects in grade VIII based on observations made in Bumiayu 1 Junior High School. PISA data in 2015 support the low ability of students in Indonesia in the science sector. Based on the data, Indonesia has an average value of 403 in the learning outcomes of science[2]. It is still far below other ASEAN countries such as Singapore which gets the number 1, while Indonesia receives 62 Low science learning outcomes, especially in high-level thinking skills, including critical thinking. The assessment of TIMSS conducted for junior high school students supports that by showing that Indonesian student fall into the characteristics of high cognitive level questions that can measure students' critical thinking abilities [3].

The causes of the low ability of students' critical thinking are that teachers do not utilize good learning strategies. Teachers still tend to use conventional learning methods, rarely use learning media and rarely link the problem of teaching materials with problems in the community. Teachers rarely use practice questions and evaluations given to students in highlevel thinking. Also, teachers tend to focus on cognitive abilities alone without training students to do scientific work on the grounds of time and facility limitations whereas scientific work can train students' activeness and critical thinking skills. 
A professional teacher must be able to apply critical thinking into the learning curriculum. By using it, students can appreciate and develop the character of critical thinking and contribute to the development of the global community [4]. Teachers as facilitators must be able to provide learning that can support critical thinking skills. Education is no longer teacher-centered but student-centered. So that students can construct the knowledge they get. Therefore learning is emphasized in the learning process. In student-centered, teachers can apply to learn to know and to learn to do.

Learning to know and learning to do are part of the four pillars of education initiated by UNESCO to welcome the 21st century. The four components of learning according to UNESCO include learning to know, learning to do, learning to live together and learning to be. Four pillars of education can facilitate students to determine to find answers of problems (learning to know) through the process of scientific work (learning to do) and collaborative process (learning to live together) so that students are accustomed to acting and being scientific (learning to be) [5].

IPA relates to efforts to systematically understand various natural phenomena. IPA not only masters facts, principles, and concepts but also a process of discovery. Scientific work can do the process. Learning to do and learning to know can present scientific work. Therefore, research is needed to determine the effect of learning to know and learning to do on science learning on critical thinking skills.

\subsection{Rationale/justification}

This research is important to be conducted because of the low critical thinking skills of students. This study will be beneficial for teachers and students, to get new learning alternatives for teachers and can improve the ability to think critically for students from the learning provided, namely learning to know and learning to do.

\subsection{Problem Statement}

This research has several problems, namely:

a. Low thinking skills of students in Indonesia.

b. Lack of teachers' ability to provide learning that trains critical thinking skills.

c. The question of task and evaluation at the level of critical thinking skills rarely appear.

\subsection{Objectives}

The purpose of this study is:

a. To find out the effect of learning to know on the critical thinking skills.

b. To determine the effect of learning to do on critical thinking skills.

c. To determine the effect of learning to know and learning to do on critical thinking skills

\subsection{Scope}

This research limits on:

a. In One school, namely Bumiayu 1 Junior High School $8^{\text {th }}$ grade.

b. Science learning materials, namely the concept of light and optics.

c. Learning to know and learning to do are given in learning science

\section{Related Works/Literature Review}

\subsection{Learning to know}


Lifelong learning based on learning to know. It is learning to acquire, deepen and utilize existing knowledge material [6]. This type of learning is very different from conventional education. In traditional learning, knowledge is given directly in a structured manner by the teacher. However, in learning to know, students seek knowledge themselves individually or in groups.

The type of learning is also known as learning to learn, meaning the learning process to get process and assimilate new knowledge and skills and find and utilize them in the context of life. That includes problem-solving and analytical thinking skills that encourage students' curiosity [7]. Also, it can develop students' abilities in memory, imagination, reasoning, and the ability to think critically [8].

The indicator of learning to know: [9]

a. Mastering and getting as much material as possible.

b. Being able to seek information from the surrounding environment and other sources.

c. Having the ability to understand beyond the teaching material received in class.

d. Develop and respond to sources of new information

e. Develop curiosity

f. Take advantage of various learning resources

\subsection{Learning to Do}

Learning to do is the application of what students have learned and known in the form of work skills. It also implies a shift from ability to knowledge [8]. Then, this type of learning is focused on work skills either to gain or apply knowledge possessed in the context of life.

In this learning activity, there are hard skills (demanding physical skills) and soft skills (requiring intellectual skills). Also, it is not only limited to mastering mechanical skills but the ability to communicate, cooperate, manage and overcome problems in concrete situations [8]. Students need academic and applied knowledge to be able to adapt to a rapidly developing environment today. Students can connect knowledge and skills, creative and adaptive, and be able to transform all these aspects into valuable skills.

It no longer has the simple meaning of learning by giving assignments to do. But it brings and seeks competence, skills, social behavior, the talent for teamwork, and initiative and readiness to take risks. It represents the application of skilled and creative knowledge. Students try how to learn effectively, think creatively, critically and historically, and how deeply to understand the information presented before them, and systemic implications for individuals and society, both in the short and long term.

The indicator of learning to know: [9]

a. Linking learning with competence

b. Bridging knowledge and skills

c. Apply their understanding and act creatively to the environment

d. Improve the skills of a student in solving daily problems

e. Learn to work or apply the knowledge gained by students

\subsection{Science}

Science is an experimental activity, but the assumption is inappropriate. IPA studies all phenomena existing in nature, both living and inanimate objects, using scientific methods as a reference for the learning process. An important goal of science learning is to help students use scientific concepts and understanding and apply scientific thinking in their daily lives [10]. Also, it can help students to generate new knowledge about nature [11]. Learning sciences since the 1975 curriculum until now requires students to develop their abilities through the use of scientific methods, practicum activities, process skills approaches, conducting experiments, 
inquiry and other approaches, including conceptual approaches [12]. Experimental activities are a small part of science learning.

Scientific methods are activities that must be carried out by scientists to obtain knowledge. The ideas found through the scientific method always show a success. The reason is that scientists cannot believe in ideas without careful testing. As a result, scientists are forced to defend their beliefs; informally in lab and symposium meetings, and officially in peer review.

Learning to do and learning to know are very suitable for science learning. If the teacher deliberately and continuously practices the science learning strategy, for example, handles real-world problems, encourages open class discussion, and develops inquiry-oriented experiments, there are excellent opportunities for developing critical thinking skills [13]. The ability to think critically is the ability needed in the process of scientific methods.

\subsection{Critical thinking}

The ability to think critically is part of high-level thinking skills (HOTS). It consists of two main points, namely critical thinking and creative thinking [1]. Critical thinking is a process of reflective thinking, productive and involves clear-directed evaluations used in solving problems, making decisions, persuading, analyzing assumptions and conducting scientific research. Besides, critical thinking is the ability to argue in an organized way and systematically evaluates personal opinions and others [1][14]. Essential skills of thinking if aligned with taxonomy blooms are at levels 4-6, namely: analysis, synthesis, and evaluation.

The indicator of critical thinking:[15]

a. Identify assumptions, arguments, and concepts

b. Giving arguments;

c. Group and classify

d. Determining cause and effect

e. Conclude

\section{Material \& Methodology}

This type of research is quantitative descriptive with experimental methods. The design of this study is the one-shot case study design. The following is a modified research design.

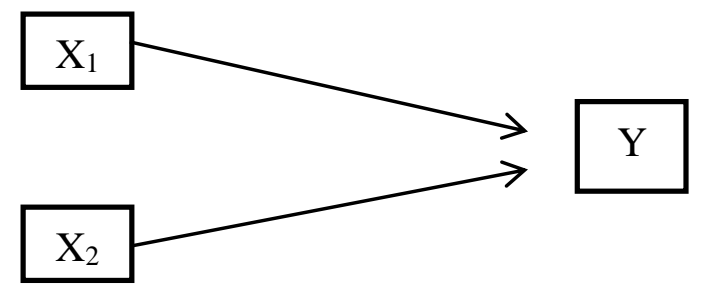

Information:

$\mathrm{X} 1$ : learning to know

$\mathrm{X} 2$ : learning to do

Y : critical thinking skills

This study uses two independent variables and one dependent variable. The independent variable is learning to know and learning to do, while the dependent variable is the ability to think critically.

The time of research is in the even semester of 2017/2018 school year in April-May 2018. The location is Bumiayi 1 Junior High School. The population was all students of class VII Bumiayi 1 Junior High School Academic Year 2017/2018. The sample is class VIII A with 32 
students. Simple random sampling technique obtained the sample. It was taken from the population randomly without considering the strata [16].

The data retrieval technique uses tests and observations. The writer obtained the data of learning to know from LKS, learning to do from observation sheets of practicum activities, and critical thinking from tests at the end of the lesson.

The data were processed using quantitative descriptive analysis techniques. Hypothesis testing utilizes a multiple linear regression tests using SPSS 16 for Windows calculation.

\section{Results and Discussion}

\subsection{Result}

Table 1. Summary of the Results of Multiple Linear Regression Test

\begin{tabular}{|l|c|c|c|c|}
\hline \multicolumn{1}{|c|}{ Variabel } & Koefsien & $\mathbf{t}_{\text {count }}$ & $\mathbf{t}_{\text {table }}$ & sig \\
\hline B.kritis (Y) & $-50,779$ & $-1,938$ & 1,699 & 0.062 \\
\hline L. to know $\left(\mathrm{X}_{1}\right)$ & 0.848 & 7.647 & 3.659 & 0.000 \\
\hline L. to do $\left(\mathrm{X}_{2}\right)$ & 0.782 & 2.169 & 2.045 & 0.038 \\
\hline F: 37.137 & sig: 0.000 & & \\
\hline R: 0.848 & $\mathrm{R}^{2}: 0.719$ & \\
\hline
\end{tabular}

The writer divides the results of analysis into the results of the regression equation, F-test, $\mathrm{t}$-test, multiple correlation and Determination $\left(\mathrm{R}^{2}\right)$.

\section{Regression equation.}

Based on the table above, the regression equation is obtained as follows: $\mathrm{Y}=-50.779+0.848 \mathrm{X} 1+0.782 \mathrm{X} 2$.

The result states that the $\mathrm{X} 1$ coefficient is 0.848 meaning that if the value of learning to know increases by 1 point, then the value of critical thinking will rise by 0.848 points, assuming X2 remains. Also, the X2 coefficient of 0.782 means that if learning to do increases by 1 point, the value added to critical thinking skills is 0.782 points, assuming X2 remains. The constant value is negative means that: if the learning variable scores learning to know and learning to do does not exist or equals 0 , then the value of critical thinking will decrease

\section{The Results of F-Test.}

The $\mathrm{F}$ test is used to find out whether learning to know and learning to do to jointly influence the ability of critical thinking in learning science significantly. Table 1 obtains the F test value of 37.137 with a significance of $0.000<0.05$. Then, the criteria reject $\mathrm{H} 0$ decision. So, simultaneously (together) learning to know (X1) and learning to do (X2) significantly affects the ability of critical thinking in learning science (Y).

\section{The Results of T-Test}

The t-test is used to determine the influence of each independent variable on a variable. Based on the calculation results, the value of $t_{\text {count }}$ on learning to know is 7.647 and with a $t_{\text {table }}$ of

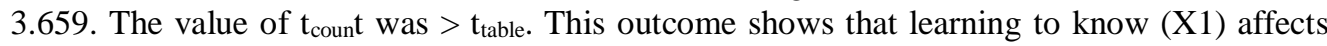
critical thinking (Y). Furthermore, it is evident that the value of $\mathrm{T}$ count on learning to do is

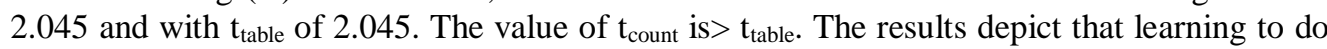
(X1) influences critical thinking (Y). 


\section{The Results of Multiple Correlation Analysis}

Correlation analysis is used to determine the relationship between two independent variables to the dependent variable simultaneously. The price of the correlation coefficient $(\mathrm{R})$ is 0.8448. This matter shows that there is a "very strong" relationship between learning to know and learning to do towards critical thinking skills.

\section{Determinant Analysis Results}

Determination analysis is used to determine the percentage contribution of the influence of independent variables simultaneously on the dependent variable. The coefficient of determination R 2 obtains figures of 0.70 or $70 \%$. This case shows that the contribution of the influence of the two independent variables on critical thinking ability is equal to $10.6 \%$. Meanwhile, other factors, not included in this study, may influence the remaining $89.4 \%$ of critical thinking abilities.

\subsection{Discussion}

This study aims to determine how extent the influence of learning to do and learning to know on the critical thinking skills in learning science, both jointly and partially. Learning to know and learning to do is part of the four pillars of education initiated by UNESCO. This research was carried out on learning science in junior high school about light and optical materials. Based on the results of the study there is an influence of learning to do and learning to know on the critical thinking skills in learning science. The magnitude of the impact is $70 \%$, while $30 \%$ influence is due to other factors not examined.

Learning to know in this research is that learning which directs students to explore the concept of light materials and optical devices independently or in groups. Students utilize various sources of information on learning to know, such as books, internet, learning videos, and other learning media. Teacher, as a facilitator, prepares all these resources. Besides, the teacher provides worksheets to guide students to discover concepts. When students have built their thoughts from learning to know, students will be able to think critically to answer the problems given by the teacher by expressing their opinions. It is evident from the results of research that learning to know partially affects the ability to think critically. Zhou (9) supported the findings by stating that learning to know can develop reasoning abilities and the knowledge of critical thinking. The ability to analyze problems, determine the adequacy of data to overcome difficulties, decide the need for additional information in a case and identify the situation is the characteristics of critical thinking [15].

In learning to do, students are given as many opportunities as possible to gain real experience and do work, such as doing a scientific experiment of the properties of light, designing a simple optical instrument, and describing the mirror image and the lens. When students are doing scientific experiment, the teacher observes and provides guidance. Through scientific work, students will be accustomed to being able to actively develop their knowledge about the problems or phenomena they encounter. This activity is under the opinion of Brunner [17] stating that the researcher can apply investigation and discovery in seeking answers to a problem. The process of the inquiry and invention is closely related to the ability of critical thinking. Learning to do represents the application of skilled and creative 
knowledge by training students to think critically about understanding the information presented, both individually and socially, both in the short and long-term [8].

Ruling on scientific performance skills in learning to do are also related to mastering knowledge through learning to know obtained by students. The process of gaining knowledge through problem-solving and finding something useful for themselves by wrestling with ideas will be more meaningful if students experience what they learn. Learning will be more meaningful if the child experiences what he learns not just knowing.

\section{Conclusion}

Based on the results of the research and discussion, below are the findings of this study:

a. There is a learning effect to know about critical thinking skills

b. There is an effect of learning to do on essential thinking skills

c. There is an influence of science learning based on four pillars of education (learning to know and learning to do) on critical thinking skills

\section{References}

[1] E. B. Johnson, Contextual teachin \& learning, 7th ed. London: Sage Publications, 2009.

[2] Pisa 2015 Results in Focus. OECD, 2018.

[3] Nizam, "Ringkasan Hasil-hasil Asesmen."

[4] C. Thompson, "Critical Thinking across the Curriculum: Process over Output," Interational J. Humanit. Soc. Sci., vol. 1, no. 9, pp. 1-7, 2011.

[5] E. Trisnawati, "Pengembangan Petunjuk Praktikum Biologi Materi Struktur Sel dan Jaringan Berbasis Empat Pilar Pendidikan,” Semarang State University, 2011.

[6] S. Zubaidah, "Keterampilan abad ke-21: keterampilan yang diajarkan melalui pembelajaran," in Seminar Nasional Pendidikan dengan tema "Isu-isu Strategis Pembelajaran MIPA Abad 21, 2016, pp. 1-17.

[7] R. Brunton, "The Four Pillars of Education," From Teach., vol. 50, no. 7, p. 2012, 2012.

[8] Z. Nan-Zhao, "Revisiting the Four Pillars of Learning," Guro21 Course 1 Required Readings, 2006.

[9] Kiswati, "Pengembangan Pembelajaran Matematika Dengan Pendekatan 4 (Empat) Pilar Pendidikan Unesco Pada Subbab Segiempat Di Kelas VIISmp Al Muhammad Cepu Blora," UIN Sunan Ampel Surabaya, 2012.

[10] S. Yoo, "Enhancing Students' Critical Thinking In Science: A Two-Year Design Based Exploration In A Large Undergraduate Science Course," The Pennsylvania State University, 2011.

[11] J. Osborne, "Teaching critical thinking ? New directions in science education," Sch. Sci. Rev., vol. 95, no. 352, pp. 53-62, 2014.

[12] N. Y. Rustaman, "Pendidikan Dan Penelitian Sains Dalam Mengembangkan Keterampilan Berpikir Tingkat Tinggi Untuk Pembangunan Karakter," in Seminar Nasional VIII Pendidikan Biologi 15 "Biologi, Sains, Lingkungan, dan Pembelajarannya Menuju Pembangunan Karakter, " 2008, pp. 15-34.

[13] B. Miri, B. C. David, and Z. Uri, "Purposely teaching for the promotion of higher-order thinking skills: A case of critical thinking," Res. Sci. Educ., vol. 37, no. 4, pp. 353-369, 
2007.

[14] J. W. Santrock, Educational Psychology, 2nd ed. McGraw-Hill Company, Inc, 2007.

[15] A. Fisher, Critical Thinking. Cambridge University Press, 2008.

[16] Sugiyono, Metode Penelitian Pendidikan Pendidikan Kuantitatif, Kualitatif, dan R\&D. Bandung: Alfabeta, 2013.

[17] A. Sugandhi, Teori Pembelajaran. Semarang: UNNES Press, 2008. 